\title{
Organisasi Kemahasiswaan antara Anomali dan Paradoks
}

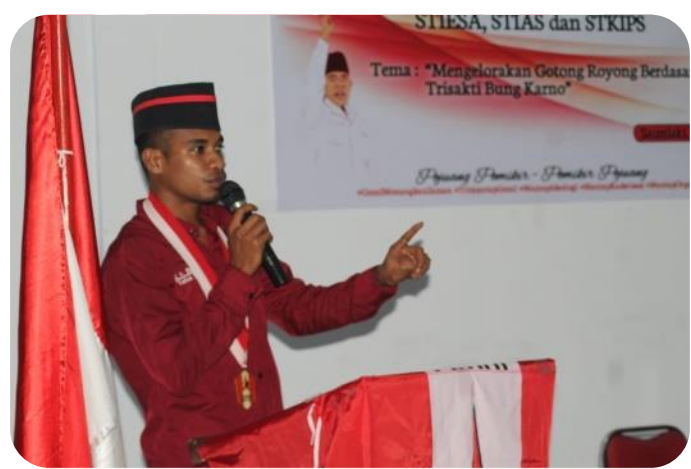

Oleh : Jois Krestofol Esauw

(Ketua GMNI Kepulauan Tanimbar)

Organisasi kemahasiswaan sejatinya adalah wadah organisasi pembelajaran, pengkaderan dan wadah perjuangan untuk melahirkan calon pemimpin yang Revolusioner, akan tetapi hari ini belum kelihatan jati dirinya baik itu organisasi intra maupun ekstara kampus yang berfungsi untuk mengasah kecerdasan intelektualnya, menjadi kuat dalam menghadapi tekanan, meningkatkan kemempuan berkomunikasi, melatih leadership, dan lain-lain. Organisasi intra kampus adalah organisasi yang memiliki kedudukan resmi dan melekat dengan kampus itu sendiri seperti Badan Eksekutif Mahasiswa (BEM), Unit Kegiatan Mahasiswa, Himpunan Mahaiswa Jurusan dan masih banyak yang lainnya. Sedangkan Organiasi Ekstra kampus adalah organisasi yang aktifitas dan kedudukannya di luar kampus dan memeliki jaringan dan kepengurusan yang berjenjang atau hirarkis hingga tingkat nasional seperti GMNI, GMKI, HMI dll.

Dinamika organisasi kemahasiswa saat ini selalu kelihatan sisi paradoksnya, di satu sisi mahasiswa di angap sebagai unsur penting perguruan tinggi tetapi di sisi lainnya masih terabaikan dan hanya di jadikan sebagai pelengkap administrasi kampus belaka. Hal Ini menunjukan bahwa oraganisasi kemahasiswaan belum menjadi wadah kematangan intelektual mahasiswa sehingga mahasiswa cenderung liar karena pilihan atau pematangannya lebih condong pada pada organisasi ekstra kampus yang sedikit banyak selalu bersentuhan dengan kekuasaan dan politik.

Miris untuk membayangkan kalau akhir-akhir ini pergerakan organisasi kemahasiswaan begitu masif, mulai kelihatan rohnya dari liang kuburnya, la bangkit dan menunjukan kepada masyarakat luas bahwa eksistensinya masih ada dan masih berperan 
sebagai penyambung lidah rakyat, akan tetapi semua yang di lakukan itu kelihatannya semu karena di lakukan atas dasar kepentingan elite, senior, dan politisi untuk mendapatkan posisi dan jabatan yang strategis dalam birokrasi sehingga independensi, daya kritis dan daya juang itu hilang entah kemana. Inilah yang saya sebut sebagai anomali dalam organisasi kemahasiswaan kita saat ini terutama di Kabupaten Kepulauan Tanimbar (KKT).

Pertanyaanya mendasarnya, mau dibawah keman oraganisasi kemahasiswaan itu ?

Dengan segala konsep pergerakan organisasi kemahasiswaan baik di kampus maupun di luar kampus, terkadang membuat saya bertanya-tanya banyak hal yang saya sendiri pun belum mampu menjawab secara komperhensif. Saya mencoba untuk mengkajinya berulang-ulang. Saya semakin muak dengan kondisi ini dimana adanya dominasi kekuasaan dan kepentingan dalam tubuh organisasi kemahasiswaan seolah diserang oleh "Virus Corona" yang kehilangan hak imunitasnya. Agar imunitas organisasi kemahasiswaan itu terus terjaga maka kita butuh refleksi dan langkah kongkrit untuk melakukan penyegaran dalam organisasi kemahasiswaan kita saat ini dengan cara :

1. menyusun rambu-rambu yang jelas untuk menjamin oraganisi kemahasiswaan dapat meaksanakan fungsinya dengan baik sebagai wadah pematangan intelektual mahasiswa baik di luar maupun di dalam kampus dan bukan sebagai pelengkap administrasi belaka.

2. Menjadikan organisasi kemahasiswaan sebagai organisasi yang independen dan mempuanyai daya juang dan daya kritis yang tinggi untuk membela dan menyuarakan kepentingan rakyat bukan sub ordinasi dari kekuasaan dan kepentingan Politik "Asal Bapak senang dan Asal Senior Senang"

3. Organisasi kemahasiswaan bukan sebagai organisasi personal yang berjuang untuk dan atas kepentingan pribadi (bisnis rente) dari kekuasaan, tetapi wadah pergerakan dan perjuangan kader secara kolektif (coletive movement) dalam mengembangkan dan memajukan oraganisasi.

4. Pergerakan organisasi kemahasiswaan harus murni sebagai sebuah gerakan sosial untuk kepentingan rakyat layaknya di lakukan seperti kerjanya "TUYUL" Kata Amtai Alaslan yang akrap di panggil Bung Allan yaitu "Gerakan senyap dengan hasil yang nyata dan pasti" tanpa ditunggangi oleh kepentingan apapun dan siapapun. 